\title{
Are Ontario Teachers Paid More Equitably? Do Local Variables Matter?
}

\author{
Xiaobin Li: Brock University, Canada
}

\begin{abstract}
This study investigated whether Ontario's education funding reform of 1998 made teacher salaries more equitable. It also examined whether selected local variables had the same influence on teacher salaries in 2001-02 as they did in 1995-96 before the reform. Average teacher salaries before the reform in 1995-96 and after the reform in 2001-02 among school boards and among census divisions were compared to see whether the variation in teacher salaries increased or decreased. A partial correlation analysis was conducted to examine the influence on teacher salaries from local variables, which were derived from a literature review. This study finds that (a) teachers are paid more equitably today than before the reform, and (b) local variables no longer really matter, as a result of the changed provincial funding formula.
\end{abstract}

\section{Introduction}

The question of how to pay teachers appropriately has long been debated in Ontario and elsewhere. In rejecting an offer of a 2 percent salary increase from the provincial government, the president of the Ontario Secondary School Teachers' Federation said in March 2005 that an increase of almost \$1 billion in education spending was needed if the government wanted to avoid teachers' strikes and fix the schools (Brown, 2005). Contracts were signed only after the government increased funding and teachers' unions retreated from their original salary increase demands.

In 1997 the Conservative government in Ontario launched a comprehensive reform in education, specified in "Education Quality and Improvement Act", commonly known as Bill 160. The government cut overall funding for education, merged school boards, reduced the honoraria for board trustees, and took away the boards' power to set local tax rates for education purposes. The government also changed the funding formula, making funding more centralized at the provincial level. Having lost the power to set tax rates, school boards no longer had the authority to determine how much they could spend.

Before the Conservative reform, Ontario's elementary and secondary education funding model was a guaranteed tax base grant plan, which generated revenues for school boards from both municipalities and the provincial government (Lawton, 1996). There was significant variation in funding across the province owing to differences in wealth among municipalities. Since the 1998 reform, education has been funded according to a provincial formula, which the government uses to calculate how much each board needs, based on its student enrolment, student characteristics, and board characteristics.

In changing the funding mechanism, the Conservative government stated that it wanted to make funding more equitable. Students should receive the same amount of financial support no matter where they live (Ontario Ministry of Education, Spring 2003). 
This study compared the variations in average teacher salaries across school boards and across census divisions in 1995-96 (before Bill 160) and in 2001-02 (after Bill 160), to see whether the funding reform has made teachers' salaries more equitable. The author assumes that the government's stated equity goal refers to horizontal equity - that is, equal treatment for equal needs. In theory, if funding for every board is the same, average teacher salaries across the province should be similar. This study also examined whether selected local variables had the same influence on average teacher salaries in 2001-02 as they did in 1995-96. Two questions were asked: (1) Are teachers paid more equitably today than before the funding reform? (2) Do local variables matter when teacher salaries are decided?

Since the last round of teacher salary negotiations, the Ontario education system has enjoyed labor peace for four years. However, most of the current contracts between school boards and teachers' unions will expire by the end of August 2008. In January 2008, Education Minister Wynne initiated informal discussions with trustee associations and teacher federations to explore new four-year collective agreements (Ministry of Education, 2008), which means how to pay teachers appropriately will again become the focus of attention. To know how to pay teachers properly, understanding whether they are paid equitably is important. It is also important to understand if and how local variables impinge on how teachers are paid, which indicates whether wealth neutrality has been achieved. Wealth neutrality is the most frequently used measurement in assessing education funding equity.

\section{Related Literature, Method, and Results}

Data for average teacher salaries in 1995-96 were collected from the Ontario Education Relations Commission (1998). Similar data for 2001-02 were collected from the Ontario Ministry of Education, Budgeting and Reporting Branch (2004). Before the funding reform there was significant variation in average teacher salaries among school boards. Table 1 displays the average teacher salaries in 1995-96 for the 122 school boards for which information is available.

Table 1

Average Teacher Salaries for School Boards 1995-1996

\begin{tabular}{lrlr}
\hline Board name & Average salary & Board name & Average salary \\
& & & \\
\hline Central Algoma & $\$ 56,482.5$ & Windsor & $\$ 58,868.0$ \\
Michipicoten & $54,793.7$ & Frontenac County & $56,081.3$ \\
Michipicoten RCSSB & $53,029.0$ & Frontenac-Lennox RCSSB & $51,879.0$ \\
North Shore & $55,783.8$ & Bruce-Grey County RCSSB & $53,533.5$ \\
North Shore District RCSSB & $53,760.0$ & Grey County & $54,392.5$ \\
Sault Ste Marie & $56,278.8$ & Haldimand & $52,772.3$ \\
Sault Ste Marie RCSSB & $56,024.0$ & Haldimand-Norfolk RCSSB & $51,226.0$ \\
Hornepayne & $53,554.9$ & Norfolk & $54,406.9$ \\
Brant County & $51,769.8$ & Haliburton County & $56,314.1$
\end{tabular}




\begin{tabular}{|c|c|c|c|}
\hline Cochrane Iroquois Falls/Blac & $57,437.1$ & Halton & $54,280.4$ \\
\hline Cochrane Iroquois RCSSB & $55,825.0$ & Halton RCSSB & $49,782.3$ \\
\hline Hearst District RCSSB & $56,919.2$ & Hamilton-Wentworth RCSSB & $57,254.8$ \\
\hline Kapuskasing-Smooth Rock & $55,081.9$ & Hamilton & $58,534.2$ \\
\hline Kapuskasing RCSSB & $54,907.7$ & Wentworth County & $54,072.2$ \\
\hline Timmins & $53,612.7$ & Hastings County & $54,517.0$ \\
\hline Timmins RCSB & $54,425.3$ & Hastings Prince RCSSB & $52,438.0$ \\
\hline Dufferin County & $53,062.8$ & Huron County & $55,982.8$ \\
\hline Durham & $52,768.2$ & Dryden & $54,240.9$ \\
\hline Durham Region RCSSB & $47,304.7$ & Dryden DRCSSB & $52,113.0$ \\
\hline Elgin County & $52,792.5$ & Kenora & $57,424.7$ \\
\hline Elgin County RCSSB & $52,220.0$ & Kenora DRCSSB & $53,271.0$ \\
\hline Essex County & $55,134.0$ & Red Lake & $51,198.8$ \\
\hline Essex County RCSSB & $51,975.5$ & Kent County & $57,215.3$ \\
\hline Windsor RCSSB & $56,018.0$ & Kent County RCSSB & $50,277.0$ \\
\hline Lambton County & $55,393.5$ & Fort Frances-Rainy River & $57,239.0$ \\
\hline Lambton County RCSSB & $55,177.2$ & Fort Frances-Rainy DRCSSB & $50,199.0$ \\
\hline Lanark County & $54,456.5$ & Renfrew County & $53,509.5$ \\
\hline Lanark Leeds RCSSB & $47,281.0$ & Renfrew County RCSSB & $52,390.0$ \\
\hline Leeds \& Grenville Co & $55,735.6$ & Simcoe County & $54,986.9$ \\
\hline Lennox \& Addington Co & $55,720.6$ & Simcoe County RCSSB & $50,239.0$ \\
\hline Manitoulin & $53,821.8$ & Stormont Dundas RCSSB & $54,539.2$ \\
\hline London \& Middlesex RCSSB & $55,167.0$ & Stormont Dundas & $52,341.8$ \\
\hline London & $54,808.2$ & Chapleau & $53,315.2$ \\
\hline Middlesex County & $53,016.2$ & Chapleau District RCSSB & $52,696.0$ \\
\hline Muskoka & $53,885.0$ & Espanola & $57,583.2$ \\
\hline Lincoln County & $55,095.0$ & Sudbury & $57,382.2$ \\
\hline Lincoln County RCSSB & $51,859.0$ & Sudbury District RCSSB & $57,875.6$ \\
\hline Niagara South & $52,876.3$ & Geraldton DRCSSB & $47,335.0$ \\
\hline Welland County RCSSB & $52,069.8$ & Lake Superior & $56,125.3$ \\
\hline Nipissing & $57,006.4$ & Lakehead & $59,568.0$ \\
\hline Nipissing DRCSSB & $55,895.9$ & Lakehead DRCSSB & $58,808.6$ \\
\hline Northumberland & $50,694.0$ & Nipigon-Red Rock & $54,452.2$ \\
\hline Carleton & $55,431.0$ & North of Superior DRCSSB & $54,585.0$ \\
\hline Carleton RCSSB & $52,586.0$ & Kirkland Lake DRCSSB & $57,519.9$ \\
\hline d'Ottawa-Carleton Conseill & $55,326.5$ & Timiskaming & $56,409.7$ \\
\hline de langue francaise d'Ottawa & $53,683.7$ & East York & $54,866.8$ \\
\hline Ottawa & $55,464.7$ & Etobicoke & $54,326.2$ \\
\hline Ottawa RCSSB & $53,412.0$ & North York & $54,960.8$ \\
\hline Oxford County & $52,699.3$ & Scarborough & $58,148.6$ \\
\hline Oxford County RCSSB & $51,578.0$ & Toronto & $55,057.0$ \\
\hline West Parry Sound & $53,028.2$ & York City & $55,162.5$ \\
\hline Dufferin-Peel RCSSB & $51,789.8$ & CELF de Toronto & $50,739.9$ \\
\hline Peel & $56,046.2$ & Metropolitan SSB & $58,146.6$ \\
\hline
\end{tabular}




$\begin{array}{lcll}\text { Huron-Perth County RCSSB } & 50,887.6 & \text { Metropolitan Toronto } & 56,681.0 \\ \text { Perth County } & 54,218.7 & \text { Victoria County } & 53,255.9 \\ \text { Peterborough County } & 54,214.6 & \text { Waterloo County } & 56,839.3 \\ \text { Prescott \& Russell Francais } & 55,342.7 & \text { Waterloo Region RCSSB } & 53,660.7 \\ \text { Prescott \& Russell County } & 49,084.2 & \text { Wellington County } & 56,098.6 \\ \text { Prescott \& Russell E. RCSSB } & 42,676.0 & \text { Wellington County RCSSB } & 50,722.0 \\ \text { Prince Edward County } & 51,378.8 & \text { York Region } & 54,651.8 \\ \text { Atikokan } & 52,012.9 & \text { York Region RCSSB } & 53,951.0\end{array}$

Note 1: RCSSB $=$ Roman Catholic Separate School Board

Note $2: \mathrm{N}=122, \mathrm{M}=\$ 54,100, \mathrm{SD}=\$ 2,643$.

Note 3: The standard deviation is about 4.9 percent of the mean.

Source: Education Relations Commission, 1998

Table 2 displays the average teacher salaries in 2001-02 for 72 school boards. Average Teachers' Salaries for School Boards 2001-2002

\begin{tabular}{lrlr}
\hline Board name & Average salary & Board name & Average salary \\
& & & \\
\hline & & & \\
DSB Ontario E. & $\$ 58,932.3$ & Northwest & $\$ 56,998.0$ \\
Algoma & $60,035.5$ & Kenora & $56,951.1$ \\
Rainbow & $58,223.8$ & Thunder Bay & $55,126.9$ \\
Near North & $59,579.4$ & Superior North & $50,852.0$ \\
Keewatin & $60,571.0$ & Bruce-Grey & $57,669.8$ \\
Rainy River & $61,194.7$ & Huron-Perth & $54,998.6$ \\
Lakehead & $60,016.6$ & Windsor-Essex & $58,741.2$ \\
Superior Green & $62,204.9$ & London & $58,567.6$ \\
Bluewater & $60,625.2$ & St. Clair & $59,983.9$ \\
Avon Maitland & $58,553.9$ & Toronto C & $61,301.8$ \\
Greater Essex & $56,550.4$ & Peterborough & $54,635.9$ \\
Lambton & $61,502.0$ & York C & $58,842.6$ \\
Thames Valley & $58,825.8$ & Dufferin & $57,338.2$ \\
Toronto & $58,506.4$ & Simcoe Musko & $53,128.2$ \\
Durham & $55,966.1$ & Durham C & $56,300.0$ \\
Kawartha & $59,033.5$ & Halton C & $54,413.2$ \\
Trillium & $59,788.6$ & Hamilton C & $56,270.9$ \\
York Region & $59,392.4$ & Wellington & $55,067.9$ \\
Simcoe & $57,783.9$ & Waterloo & $57,430.0$ \\
Upper Grand & $58,219.2$ & Niagara C & $51,289.0$ \\
Peel & $57,955.1$ & Brant Haldimo & $56,119.8$ \\
Halton & $58,095.4$ & E. Ontario & $53,887.5$ \\
Hamilton & $58,306.0$ & Ottawa-Carlton & $57,368.4$ \\
& & &
\end{tabular}




\begin{tabular}{llll} 
DSB of Niagara & $58,325.7$ & Renfrew & $54,202.2$ \\
Grand Erie & $60,484.0$ & Algonquin & $56,542.2$ \\
Waterloo & $60,480.2$ & CSD Nord-Est & $52,859.3$ \\
Ottawa & $57,219.4$ & CSD Grand N. & $57,066.7$ \\
Upper Canada & $58,231.2$ & CSD Centre & $51,133.7$ \\
Limestone & $58,362.8$ & CSD desecole & $53,173.5$ \\
Renfrew & $54,774.9$ & CSD desGrand & $57,972.6$ \\
Hastings & $56,304.8$ & CSD FrancoNo & $52,690.9$ \\
Northeast & $52,754.2$ & CSDdueNouve & $56,693.4$ \\
Nipissing & $55,521.9$ & CSD Aurores & $48,405.9$ \\
Huron-Superio & $56,619.5$ & CSD ecolescat & $51,145.6$ \\
Sudbury & $57,646.9$ & CSD CentreSu & $51,413.8$ \\
CSD del'Esto & $55,908.4$ & CSD duCentre & $54,760.0$ \\
& & & \\
\hline
\end{tabular}

Note 1: C = Catholic; $\mathrm{CSD}=$ Conseil Scolaire de District (District School Board)

Note $2: \mathrm{N}=72, \mathrm{M}=\$ 56,859, \mathrm{SD}=\$ 2,919$

Note 3: The standard deviation is about 5.1 percent of the mean.

Source: Author's calculations from Ontario Ministry of Education data, 2004

The 1995-96 standard deviation, 4.9 percent of the mean, is actually smaller than the 2001-02 standard deviation, 5.1 percent of the mean. However, the difference between the two standard deviations for 1995-96 and 2001-02 is only $\$ 276$. The two standard deviations can be considered quite close. The results indicate that the variation in average teacher salaries in 2001-02 was similar to that in 1995-96. Does this mean the situation in 2001-02 was as inequitable as in 1995-96? It is difficult to give a yes-or-no answer without looking at certain local variables that can affect how teachers are paid. An effort to see whether selected variables have an impact on teachers' salaries will help answer the equity question.

Chambers and Fowler (1995) used a hedonic model to develop a teacher cost index across the United States. In an earlier article, Chambers (1981) described the hedonic model as follows:

The intuitive notion underlying this theoretical structure is that individuals care both about the quality of their work environment as well as the monetary rewards associated with particular employment alternatives, and that they will seek to attain the greatest possible personal satisfaction by selecting a job with the appropriate combination of monetary and non-monetary rewards. Similarly, employers are not indifferent as to the characteristics of the individuals to whom they offer particular jobs. The result of these simultaneous choices is the matching of individual employees with employers. It is the result of this matching process itself that reveals implicitly the differential rates of pay associated with the attributes of individual employees and the working conditions offered by employers. More formally, it is the supply of, and demand for, individuals with certain personal attributes to any particular kind of job assignment that determines 
the equilibrium wages of labour as well as the implicit market prices attached to the personal and job characteristics.

The implicit relationship observed between wages and the personal and job characteristics of individuals is referred to as a hedonic wage index ... The hedonic wage index permits one to decompose the observed variation in the wages paid to labour into the dollar values attached to each unit of the personal and workplace characteristics. (p. 51)

McMahon and Chang (1991) point out that in the United States there is a 74 percent difference in the cost of living between the higher cost cities and the lowest cost nonmetropolitan areas (p. 16). The main difference between cities and non-metropolitan areas is population density. "In general, more densely populated areas and the large urban areas exhibit significantly higher teacher salaries. One standard deviation above the mean in metropolitan area population is associated with a 6.5 percent salary differential" (Chambers \& Fowler, 1995, p. 39).

Local wealth, indicated by average family income, is another factor often considered (Alexander \& Salmon, 1995). An area's socioeconomic status decides the financial ability of the local government and influences its willingness and capacity to spend on public education.

Increasingly, geographic differences in the cost of living are a factor in collective bargaining. Cost of living is measured in various ways. Two variables often used to measure the cost of living are land prices and population growth. "The basic land values affect the local costs of producing goods and services and hence the cost-of-living differences across regions" (Chambers \& Fowler, 1995, p. 39). If the population grows, "changes in the population affect local demand for goods and services and reflect upward pressures on local prices and hence costs of living" (Chambers \& Fowler, p. 39).

In addition, the general labor market influences whether people want to enter teaching, whether they remain in teaching, and how teachers are paid (Lewis \& Norris, 1992, pp. 260-277; Jacobson, 1996). In British Columbia, Awhen the economy is improving and more job opportunities are present, more teachers are likely to choose to resign. In contrast, rising unemployment rates and the lack of job openings tend to inhibit teachers from leaving the profession $\cong$ (British Columbia Teacher Supply and Demand Committee, 1994, p. 5).

Finally, weather sometimes plays a role when people decide where to work. People prefer to live in warm and sunny places, especially in a northern country like Canada. It is reasonable to assume that teachers act in the same way. Colder places need to provide higher salaries to attract and keep people. AThe notion is that individuals would trade off salaries to live and work in regions with more favourable climates $\cong$ (Chamber \& Fowler, 1995, p. 42).

A review of the relevant literature suggests that six factors need to be considered when analyzing variations in teacher salaries. These six factors are population density, family income, land price, population growth, unemployment rate, and weather. These six factors are independent variables expected to influence the dependent variable, the average teacher salaries. 
The partial correlation procedure in SPSS was conducted to test whether the six independent variables had a correlation with the dependent variable, whether the correlation was positive if there was one, and how strong the correlation was. The author hypothesized that relationships existed between the dependent variable and the six independent variables. The following six hypotheses were tested:

1. The greater the population density, the higher teacher salaries tend to be, other things being equal.

2. The higher the average family income, the higher teacher salaries tend to be, other things being equal.

3. The higher the average farmland price, the higher teacher salaries tend to be, other things being equal.

4. The higher the population growth, the higher teacher salaries tend to be, other things being equal.

5. The higher the unemployment rate, the lower teacher salaries tend to be, other things being equal.

6. The warmer the climate, the lower teacher salaries tend to be, other things being equal.

In this study, teacher salaries were the average salaries in publicly funded elementary and secondary schools. Data on average teacher salaries in 2001-02 from 60 English boards were calculated to produce the combined average salary for both elementary and secondary teachers for each census division. The average teacher salaries among 49 census divisions were compared to determine whether significant variation existed. Census divisions, not school boards, were used as units of analysis, because for five independent variables data were available from Statistics Canada only at the census division level. Average teacher salaries from 60 English school boards were calculated to generate data approximately at the census division level. The 12 French boards' average teacher salaries were not used, because for 49 census divisions there are only 12 French boards, i.e., each French board covers several census divisions. Using French boards' data would have reduced the variation in teacher salaries among census divisions.

Some English boards have similar boundaries with census divisions of the same name. In these census divisions, average teacher salaries from the public board and the Catholic board were calculated to generate an average for the census division. Other school boards cover more than one census division. For example, Limestone District School Board and Algonquin Lakeshore Catholic School Board both cover two census divisions, Frontenac and Lennox-Addington. Average salaries from the Limestone and Algonquin Lakeshore boards were calculated to obtain an average for Frontenac and LennoxAddington. Census divisions in a similar situation had their average salaries calculated in the same way. One census division, Thunder Bay, has four boards in it: Lakehead District School Board, Superior-Greenstone Board, Thunder Bay Catholic Board, and Superior North Catholic Board. Average salaries from these four boards were calculated to arrive at an average for Thunder Bay. The boundaries of district school boards and census divisions can be viewed at the websites of Ontario Ministry of Education (May 13, 2003) and Statistics Canada (January 20, 2003). 
Data for 49 census divisions on 2001 population density, average family income, average farmland price, unemployment rate, and 2000-2001 population growth were obtained from Statistics Canada (2002; March 12, 2002; 2003a, 2003b, May 2003). Daily average temperature for 49 census divisions was taken from Environment Canada (2005). Table 3 displays average teacher salaries calculated for 49 census divisions in 2001-02.

Table 3

Average Teachers' Salaries for Census Divisions 2001-2002

\begin{tabular}{|c|c|c|c|}
\hline Algoma & $\$ 58,940.08$ & Middlesex & $\$ 58772.38$ \\
\hline Brant & $59,364.88$ & Muskoka & $57,416.30$ \\
\hline Bruce & $60,184.18$ & Niagara & $55,920.35$ \\
\hline Chatham & $61,051.05$ & Nipissing & $58,651.01$ \\
\hline Cochrane & $57,592.58$ & Northumberland & $57,416.30$ \\
\hline Dufferin & $57,688.05$ & Ottawa & $53,043.48$ \\
\hline Durham & $56,060.63$ & Oxford & $58,772.38$ \\
\hline Elgin & $58,772.38$ & Parry Sound & $58,651.01$ \\
\hline Essex & $57,444.41$ & Peel Region & $57,688.05$ \\
\hline Frontenac & $57,203.81$ & Perth County & $57,835.58$ \\
\hline Greater Sudbury & $58,052.76$ & Peterborough & $57,416.30$ \\
\hline Grey County & $60,184.18$ & Prescott & $56,953.07$ \\
\hline Haldimand & $59,364.88$ & Prince Edward & $57,203.81$ \\
\hline Haliburton & $57,416.30$ & Rainy River & $60,069.27$ \\
\hline Halton Region & $56,773.22$ & Renfrew & $54,594.54$ \\
\hline Hamilton & $57,624.15$ & Simcoe County & $57,416.30$ \\
\hline Hastings & $57,203.81$ & Stormont & $56,953.07$ \\
\hline Huron & $57,835.58$ & Sudbury & $58,052.76$ \\
\hline Kawartha & $57,416.30$ & Thunder Bay & $58,421.93$ \\
\hline Kenora & $60,023.04$ & Timiskaming & $57,592.58$ \\
\hline Lambton & $61,051.05$ & Toronto & $59,208.73$ \\
\hline Lanark & $56,953.07$ & Waterloo & $59,620.78$ \\
\hline Leeds & $56,953.07$ & Wellington & $57,688.05$ \\
\hline Lennox & $57,203.81$ & York Region & $59,207.25$ \\
\hline Manitoulin & $58,052.76$ & & \\
\hline
\end{tabular}

Note: $\mathrm{N}=49, \mathrm{M}=\$ 58,065.31, \mathrm{SD}=\$ 1,299.99$

Source: Author's calculations from Ontario Ministry of Education data, 2004

The standard deviation is about 2 percent of the mean. The standard deviation is smaller than the one found in 1995-96, which was about 3 percent of the mean $(\mathrm{Li}$, 2002). The partial correlation procedure was conducted to test each of the six hypotheses. 
Table 4 displays the results of the partial correlation analysis.

Partial Correlation Coefficients for Six Independent Variables 2001-2002

\begin{tabular}{|c|c|c|c|c|c|c|}
\hline Density & Familyin & Landpric & Popugrow & Unemploy & Weather & \\
\hline Salary & -.25 & .03 & .24 & -.04 & .26 & .11 \\
\hline \multicolumn{7}{|c|}{ Controlling: } \\
\hline & Familyin & Density & Density & Density & Density & Density \\
\hline & Landpric & Landpric & Familyin & Familyin & Familyin & Familyin \\
\hline & Popugrow & Popugrow & Popugrow & Landpric & Landpric & Landpric \\
\hline & Unemploy & Unemploy & Unemploy & Unemploy & Popugrow & Popugrow \\
\hline & Weather & Weather & Weather & Weather & Weather & Unemploy \\
\hline \multicolumn{7}{|c|}{ Hypothesized } \\
\hline correlation: & + & + & + & + & - & - \\
\hline
\end{tabular}

Since population data were used, no significance testing was necessary. The results of the partial correlation analysis indicate that between population density and average teacher salaries there is a surprisingly negative correlation $(r=-.25)$ at the census division level, contrary to the hypothesis.

There is a very weak positive correlation between family incomes and teacher salaries $(\mathrm{r}=.03)$, confirming the hypothesis. There is a low positive correlation between farmland prices and teacher salaries $(r=.24)$, confirming the hypothesis again.

There is a very weak negative correlation between population growth and teacher salaries $(\mathrm{r}=-.04)$, contrary to the hypothesis. There is a low positive correlation between unemployment rates and teacher salaries $(\mathrm{r}=.26)$, again contrary to the hypothesis. There is a weak positive correlation between weather and teacher salaries $(r=.11)$, also contrary to the hypothesis.

\section{Discussion}

It is difficult to determine why there is a weak negative correlation between population density and teacher salaries at the census division level. This unusual phenomenon merits further investigation.

The positive correlation between family incomes and teacher salaries confirms the hypothesis, but at .03 the relationship is very weak. There is a significant, albeit low, positive correlation between farmland prices and teacher salaries, as hypothesized. This result confirms what Chambers and Fowler (1995) found in their study.

For the surprisingly negative correlation between population growth and teacher salaries, the explanation is that as population grows in a census division, often so does 
student enrolment. As enrolment grows, schools must hire more teachers, who tend to be new teachers paid at entry-level salaries, lowering the average salary.

For the surprisingly positive correlation between unemployment rates and teacher salaries, a highly possible explanation is that there is rigidity in the public sector's response to the ups and downs of the marketplace, especially when the sector is unionized (Dwayne, Gunderson, \& Riddell, 2002). In Canada, all teachers in publicly funded schools belong to a union. Collective agreements between unions and school boards may reflect this rigidity in responding to the marketplace. In 2001-02, most collective agreements between teachers and school boards were for two or three years. This further complicates how the local economy affects the compensation of teachers. In addition, the funding formula has a "learning opportunities allocation" for socially and economically depressed areas, to reflect the higher cost of educating disadvantaged students. Is it possible that census divisions with higher unemployment rates receive a higher learning opportunities allocation and that these boards are able to pay teachers higher salaries? Whatever the case, the positive correlation is puzzling and warrants further exploration.

Contrary to the hypothesis, there is a positive albeit very low correlation between daily average temperature and teacher salaries. It is difficult to explain why.

Overall, the results from the partial correlation analysis concerning the relationships between the six independent variables and the dependent variable at the census division level contradict four out of the six hypotheses. Regarding the two relationships that confirm the hypothesis, the positive relationship between family incomes and teacher salaries is very weak, at only .03. In most cases, inequity in education financing arises from differences in local wealth. The Conservative government launched its education reform in part to make funding more equitable. In the late 1990s a study was conducted that investigated the relationships between the same six independent variables and the dependent variable for census divisions in Ontario. That study found that in 1995-96 out of the six independent variables four had an impact on average teacher salaries as hypothesized (Li, 2002). Table 5 displays the partial correlation analysis results of that study.

Table 5

Partial Correlation Coefficients for Six Independent Variables 1995-1996

\begin{tabular}{lllllll}
\hline Density & Familyin & Landpric & Popugrow & Unemploy & Weather & \\
\hline Salary & .02 & .16 & .13 & -.35 & .25 & -.16 \\
\multicolumn{1}{c}{ Controlling: } & & & & & \\
& & & & & \\
& Familyin & Density & Density & Density & Density & Density \\
& Popugrow & Popugrow & Familyin & Familyin & Familyin & Familyin \\
& Landpric & Landpric & Popugrow & Landpric & Popugrow & Popugrow \\
Unemploy & Unemploy & Unemploy & Unemploy & Landpric & Landpric \\
& Weather & Weather & Weather & Weather & Weather & Unemploy
\end{tabular}


Hypothesized correlation: + $+$ $+$

Table 4 indicates that in 2001-02 the positive correlation between family incomes and teacher salaries for census divisions was very weak at .03, much smaller than the .16 correlation in 1995-96 (see Table 5). Family income is the most important independent variable influencing teacher salaries inter-provincially as well as intra-provincially $(\mathrm{Li}$, 2002). The funding for education at the census division level was more equitable in 200102 than in 1995-96, because the influence of local residents' wealth on teacher salaries had been reduced from .16 to .03 .

In addition, the influence of population density was reversed. The positive correlation in 1995-96 became a negative one in 2001-02, contradicting the hypothesis. It is difficult to determine, however, whether this is a good thing or bad thing.

The answer to the first question, "Are Ontario teachers paid more equitably?" is, "Yes." In 2001-02 teachers in publicly funded schools in Ontario were paid more equitably at the census division level than they had been in 1995-96, because the reform significantly reduced the influence of local residents' wealth. This is confirmed by the fact that the ratio of the standard deviation to the mean of average teacher salaries was reduced from 3 percent in 1995-96 to 2 percent in 2001-02.

The answer to the second question, "Do local variables matter?" is, "Probably they do not." As a result of the provincial funding formula, local variables do not really matter any more in deciding how teachers are paid. Out of the six independent variables hypothesized to have an impact on average teacher salaries, four have a correlation contrary to the hypothesis. Regarding the two variables confirming the hypothesis, the impact of family income has been greatly reduced.

However, in 2001-02 the variation in average teacher salaries among school boards was similar to what it had been in 1995-96 (see Tables 1 and 2). This is surprising. Every board had been funded in the same way, so why did average teacher salaries vary among school boards in 2001-02 as they had among boards in 1995-96? Since every board is funded according to the same formula, most expenditures should be similar, including teacher salaries, which are the most important item in education budgets.

One explanation is that school boards may use their allotted money in different ways. For example, in 2003-04 Toronto District School Board gave schools about 3 percent of what they were entitled to according to the formula. But Halton District School Board gave their schools about 1.44 percent of what they were entitled to. With different proportions of the money at their disposal, boards may be able to pay their teachers a little differently. Since teacher salaries are decided at the board level, it can happen that teachers employed by different boards are paid differently.

Other factors may help explain why a noticeable variation in average teacher salaries exists among school boards. For example, student/teacher ratios may vary. Provincial guidelines stipulate average class sizes for schools, but how closely do boards 
follow those guidelines? If different boards have different class sizes, the different class sizes will have an impact on how teachers are paid. In addition, boards have discretion in using some allocations, of which one is the language allocation. It is reported that some boards use the money from the language allocation elsewhere (People for Education, 2008; Rushowy, 2007).

Finally, teachers are paid differently according to their education and experience: more experienced teachers and those with more training are paid more, which should affect average teacher salaries. Enrolment at Toronto Catholic School Board has been declining in recent years, but enrolment at Halton Catholic School Board has been increasing. Proportionately, the Toronto board is hiring fewer new teachers than the Halton board; as a result, there is a higher proportion of new teachers at Halton, reducing the average salary of teachers there. Table 2 indicates that Toronto Catholic School Board's average teacher salary was $\$ 61,302, \$ 6,889$ higher than $\$ 54,413$ at Halton. Actually, in the funding formula there is an allocation, the "teacher qualification and experience allocation," that helps school boards with more senior teachers offset the higher salaries they have to pay. This makes relating variables with average teacher salaries more complicated.

In most boards a teacher with a master's degree - usually a Master of Education degree - is paid more than a teacher with a Bachelor of Education degree. If school board A has more teachers with a Master of Education degree than board B, average teacher salaries in board A will be higher.

Unfortunately, the data associated with these two important variablesexperience and education - are not available at the present time. If they had been, the research might have been more accurate. The available data and analyses are not ideal; they are approximations that offer us some insight into how equitably teachers are paid and whether selected local variables affect how teachers are paid at the census division level.

One limitation of this study is that the data from school boards and census divisions were matched approximately. In the process, inaccuracies may have arisen. A closer look at the funding formula itself and its impact on school boards may help us understand why variation still occurs in average teacher salaries across school boards. Another limitation of this study is that benefits have not been included in the analysis, and benefits may vary from board to board.

Should every teacher be paid the same when the cost of living varies across the province? For example, in Toronto-Canada's largest city with more than two million residents - house prices are much higher than in Kenora, a town in the province's northwest part. Should teachers in Toronto and Kenora be paid the same? Most people would say they should not, yet the current funding formula does not directly consider living costs. However, this study did find a positive correlation between one indication of the cost of living - land price - and average teacher salaries at the census division level. That is, where land prices are higher, teachers tend to receive higher salaries. Since the formula does not consider land prices, this finding merits further investigation. In deciding teacher salaries, is it possible to develop a mechanism to compare the cost of living in different locations? 
Teacher salaries are negotiated locally, between union locals and school boards. Would provincial bargaining for all teachers and all boards be more equitable and more effective? Or would a regional bargaining for teachers and boards be more equitable and more effective? For example, the province could be divided into several economic regions according to Statistics Canada data. These questions deserve to be considered.

Teacher salaries are the largest item in education expenditures. Understanding whether teachers are paid equitably and whether local variables affect how they are paid helps us better comprehend their working conditions, which contributes toward decisionmaking that moves education along constructive paths. In addition, most teacher contracts in Ontario will expire at the end of August 2008. How to pay teachers appropriately will once again become the focus of attention. 


\section{References}

Alexander, K., \& Salmon, R. (1995). Public school finance. Boston, MA: Allyn and Bacon.

British Columbia Teacher Supply and Demand Committee. (1994). Teacher supply and demand in British Columbia, 1994-2013. Victoria, BC: Author.

Brown, L. (2005, March 15). Schools need \$1 billion fix, teachers say. Toronto Star, p. B2.

Chambers, J. (1981). Cost and price level adjustments to state aid for education: A theoretical and empirical review. In F. Jordan (Ed.), Perspectives in state school support programs, Second annual yearbook of the American Educational Finance Association, Cambridge, MA: Ballinger Publishing Company.

Chambers, J., \& Fowler, W. (1995). Public school teacher cost differences across the United States. Washington, D.C.: American Institutes for Research in the Behavioural Sciences.

Environment Canada. Canadian Climate Normals or Averages 1971-2000. Retrieved January 4, 2005, from http://www.climate.weatheroffice.ec.gc.ca/climate _normals/stnselect_e.html

Dwayne, B., Gunderson, M., \& Riddell, C. (2002). Labour market economics. Toronto, ON: McGraw-Hill Ryerson.

Jacobson, S. (1996). Monetary incentives and the reform of teacher compensation: A persistent organizational dilemma. In S. Jacobson, E. Hickcox \& R. Stevenson (Eds.), School administration: Persistent dilemmas in preparation and practice. West Port, Connecticut: Praeger.

Lawton, S. (1996). Financing Canadian education. Toronto: Canadian Education Association.

Lewis, P., \& Norris, K. (1992). Demand, supply and adjustment in the teachers labour market. Australia Journal of Education, 36(3), 260-277.

Li, X. (2002). Variation in average teacher salaries among Canadian provinces and its probable reasons. Journal of Education Finance, 27(3), 909-929.

McMahon, W., \& Chang, S. (1991). Geographical cost of living differences: Interstate and intrastate, update. Normal, IL: Centre for the Study of Educational Finance, Illinois State University.

Ontario Education Relations Commission. (1998). Compensation of teachers in school boards 1995-1996. Toronto, ON: Author.

Ontario Ministry of Education. (2003, May 13). School board profiles. Retrieved August 5, 2008, from http://esip.edu.gov.on.ca/english/core/BoardByBoundaryMap.asp 
Ontario Ministry of Education. (2003, Spring). Student-focused funding: parents guide. Retrieved September 10, 2003, from http://www.edu.gov.on.ca/eng/funding/0304/ funding.pdf

Ontario Ministry of Education. (2004). Average teacher salary from school boards. Toronto, ON: Budgeting and Reporting Branch, Ontario Ministry of Education.

Ontario Ministry of Education. (2004, Spring). Legislative grants 2004-05. Retrieved August 1, 2008, from http://www.edu.gov.on.ca/eng/funding/0405/funding.pdf

Ontario Ministry of Education. (2007, Spring). School board funding projections for the 2007-08 school year. Retrieved August 1, 2008, from http://www.edu.gov.on.ca/ eng/funding/0708/funding.pdf

Ontario Ministry of Education. (2008). Provincial Discussion Tables (PDTs). Retrieved August 4, 2008, from http://www.edu.gov.on.ca/eng/document/nr/08.07/PDT.html

People for Education. (2008). The annual report on Ontario's public schools 2008. Retrieved August 5, 2008, from http://www.peopleforeducation.com/reportonschools08

Rushowy, K. (2007, June 13). ESL funds used to heat schools. Toronto Star, p. A8.

Statistics Canada. (2002). 2001 Census of agriculture. Ottawa, ON: Catalogue number 95F0301XIE.

Statistics Canada. (2002, March 12). Population and dwelling counts, for census divisions, census subdivisions (municipalities) and designated places, 2001 and 1996 censuses - $100 \%$ data. Ottawa, ON: Author, Catalogue no. 93F0050XCB2001003.

Statistics Canada. (2003a). Annual demographic statistics, 2002. Ottawa, ON: Author.

Statistics Canada. (2003b). Census of Canada 2001. Ottawa, ON: Author, Catalogue no. 95F0436XCB-01006.

Statistics Canada. (2003, January 20). Reference maps. Retrieved August 4, 2008, from http://geodepot.statcan.ca/Diss/Maps/ReferenceMaps/cd_csd_e.cfm?ProvCode=3 $5 \&$ Prname $=$ Ontario \& startrow $=1$

Statistics Canada. (2003, May). Census of Canada 2001. Ottawa, ON: Author, Catalogue no. $95 \mathrm{~F}$. 